\title{
Heritage of Hindu-Buddhist Thought: Pradaksina and Prasavya Perspective in Tantu Panggelaran Text
}

\author{
T I Setyani \\ Departement of Literature Studies, Faculty of Humanities, Universitas Indonesia, Indonesia \\ turita.indah@gmail.com
}

\begin{abstract}
This research discusses about pradaksina and prasavya perspective in The Tantu Panggelaran (TP) text related to the cosmic configuration that occurs as a basis for balancing Java. Therefore, the purpose of this research is to express the perspective of pradaksina and prasavya in TP texts as a Hindu-Buddhist thought heritage. This study uses the interpretative theory in the perspective of Hindu-Buddhist religious thoughts. The results showed that the perspective of pradaksina and prasavya in the TP text based on Hindu-Buddhist thought inheritance has specificity in the formation of the cosmic configuration of Java Island. The pradaksina pattern represents the purification of the island of Java, while the prasavya pattern represents the sacred zone of Java Island which is centered on the Kukub mandala. That matter refers to the direction of Bhatāara Guru when he carried out yoga, facing west and east in new Old Javanese prose. Thus, it can be inferred that the representation of pradaksina and the prasavya in the TP text as a relic of the new Old Javanese prose based on the purification and the formation of the sacred zone of the island of Java is a Hindu-Buddhist thought in an effort to make balance of Java towards its perfection as Javanese culture, especially the Old Javanese culture from the era of late Majapahit.
\end{abstract}

Keywords: Hindu-Buddhist Thought, Tantu Panggelaran Text, Pradaksina, Prasavya.

\section{INTRODUCTION}

Mandala in Hindu-Buddhist thoughts have a very important role as the center of balance of the macrocosm and microcosm. The center of balance is closely related to the cardinal points that determines the cosmic configuration. The cosmic configuration represents plotting or the hierarchical point regarding the position of the deities. The configuration representation is the unity of the universe (the macrocosm) and human (microcosm) which is centered on one point 
in the cosmic circle. The configuration of the mandala's shape from a circle centered on one point later develops into a rectangle representing the four cardinal points. Some statements reveal that the wind direction contained in the TP is somewhat different from the cosmic configuration that is generally known, both from previous Javanese literary works as well as in the sacred building evidence found on Java [1],[2],[3].

According to Swellengebel (1936) in Edi Sedyawati, generally in Old Javanese literature, a large mountain range in Jambudwipa is located in the north-south direction. The direction is a picture of the range of the world or nature, but between the news of old prose and new prose is different. In old prose, which is still close to its Indian source, it is known that the large mountains in Jambudwīpa stretch in the north-south direction [3], as in Diagram 1.

The cardinal points are forms of group placement of deities as the Mūrtyaștaka of Śiwa, who became known as Nawasanga [4]. In new prose, like TP text, the range of the cardinal points in the east-west. For example, in the distribution of bhairawapakșa monasteries in Java [5]. That affected the cosmic configuration that occurred in Java. In the other hand, it can also influence the religious concepts contained in it. It is possible that the poet of the TP had other experiences that were somewhat different from the views, thoughts, and religious experiences of the previous poets. Therefore the interrelationship between the cosmic configuration of Java in the TP text is important to be studied.

Referring to this view and the reality contained in the TP text, this study seeks to reveal more about the cosmic configuration of Java Island according to the background of the creation of text based on the perspective of Hindu-Buddhist thought.

The source of research data is the old Javanese TP text edited by T G H Pigeaud (1924) found on page 57-128 of his dissertation entitled De Tantu Panggělaran Een Oud-Javaanch Proza-Geschrift, Uitgegeven, Vertaald en Toegelicht.

\section{METHOD}

This study aims to reveal the perspective of pradaksina and prasavya in TP texts as a Hindu-Buddhist thought heritage. The objective will be discussed using interpretative theory in the perspective of Hindu-Buddhist religious thinking and objective approach. Interpretative theory is utilised to understand the text as a whole. The comprehension of the text is more focused on the cosmic configuration of TP texts in the perspective of Hindu-Buddhist religious thoughts. The understanding refers to interpretations that give the impression and view of something related to the interpretation of the formation cosmic configuration. This interpretation is an attempt to interpret according to what is written in the TP text. Thus, the objective approach is considered appropriate to be utilised in this discussion, in order to be able to place the TP text as an autonomous literary work.

The significance of this research, theoretically, can provide new knowledge about the configuration of mandala formation as the cosmic configuration of Java, especially those found in the TP text. Conceptually, this research can be used as a basis for conducting further research related to the cosmic configuration of Java. 


\section{RESULT AND DISCUSSION}

In the introduction it has been stated that in the news of old prose, a large mountain range in Jambudwipa is located in the north-south direction. In the news of new prose, TP describes of the scattered mountains of Mahameru in various places on Java, located in the east-west direction.. Those points affected the position of the deities who occupied every point. The central point located at Mount Mahāmeru is the place of the Bhatara Guru (Śiwa) with the placement of deities at four different points of the wind, as in Diagram 2.

Diagram 1. According to Swellengebel

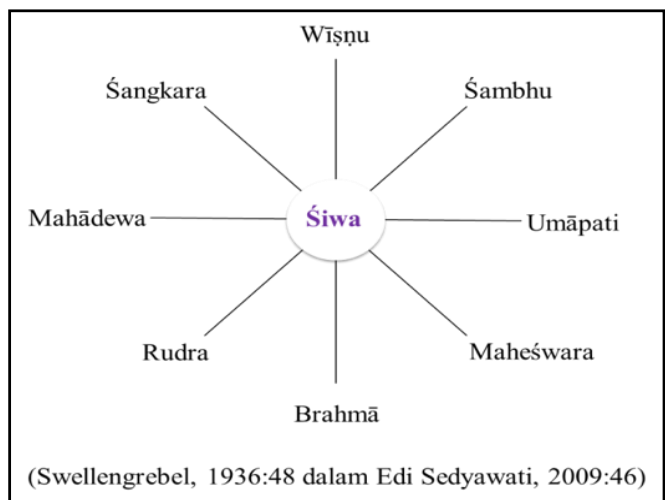

Diagram 1. According to Tantu Panggelaran

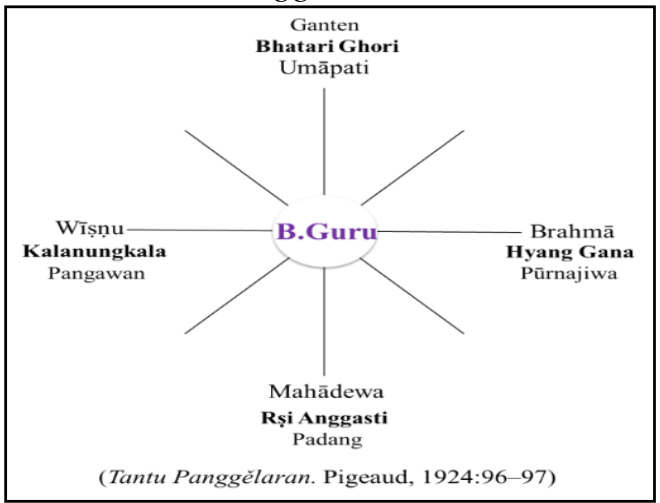

The difference in the placement of deities in the cardinal points with the east-west symmetrical pattern is still a remaining question. In the TP text, it is stated that Bhatārā Guru tries to face east when he will try to strengthen the unstable island of Java [4]. This question is important because it affects the disposition of mountains and certainly also affects the geographical location of the mandala contained in the TP text.

The concept of mandala throughout the world is perceived to be based on Hindu thoughts, which is divided into groups consisting five parts with four sides in each cardinal points and one central point crossing from the four points [5]. Similarly, referring to the formation of mandalas in the TP text based on Hindu-Buddhist religious thoughts, are positioned in a circle centered crossing from the four points. Overall, the process of forming a mandala is based on its geographical location, from those located in the mountain range, to those located in the four cardinal points against Mount Mahameru, centered on a mandala located on Mount Mahameru. The geographical location of the mandalas in the TP text, which numbered 40 mandalas, can be divided into three locations as follows: a) In the Mount Mahameru region; b) In the Mountainous region; and c) Besides a and $b$. However, to reveal the basics of the cosmic configuration of Java Island, here will only be presented with mandalas located in the Gunung Mahameru area.

The geographical location of the mandalas represents the cosmic configuration of Java as a form of inter-mandala connection. The configuration represents the unity of the macrocosm centered on one point in the cosmic circle. The configuration of mandala formation from a circle centered on one point crossing from the four cardinal points.

The clue to the center that became the crossing point Kukub mandala, on Mount Mahameru. Then to the west of Mount Mahameru, in the area of Mount Kelaça there is a 
Sukayajñā mandala. To the south of Mount Mahameru there is the Çūnyasagiri mandala. To the east of Mount Mahameru is Gerěsik mandala. The Andawar mandala shows that it is located in the northern part of Mount Mahameru, because it is located on the slope between Mount Mahameru and Mount Brahma [4]. Referring to the geographical location of the mandalas, the center point of the cosmic configuration of Java Island is situated on Mount Mahameru.

Specifically, Munandar has made a chart regarding Mount Pawitra (Mahameru) with mountains originating from the ruins of Mount Mahameru, according to those found in the TP text [6] (see Diagram 3).

However, the mountain configuration chart with Pawitra on the center, if applied to the mandala configuration centered on the Kukub mandala, then according to TP text the disposition will change the position of the cardinal points from the location of the mandala located on the mountains. When illustrated it might look like in the Diagram 4.

Diagram 3. Configuration Diagram of Mountains with Pawitra as The Center
Diagram 4. Configuration Diagram of Mandalas with Kukub Mandala as The Center [4] According to the Diagram 1 [6]

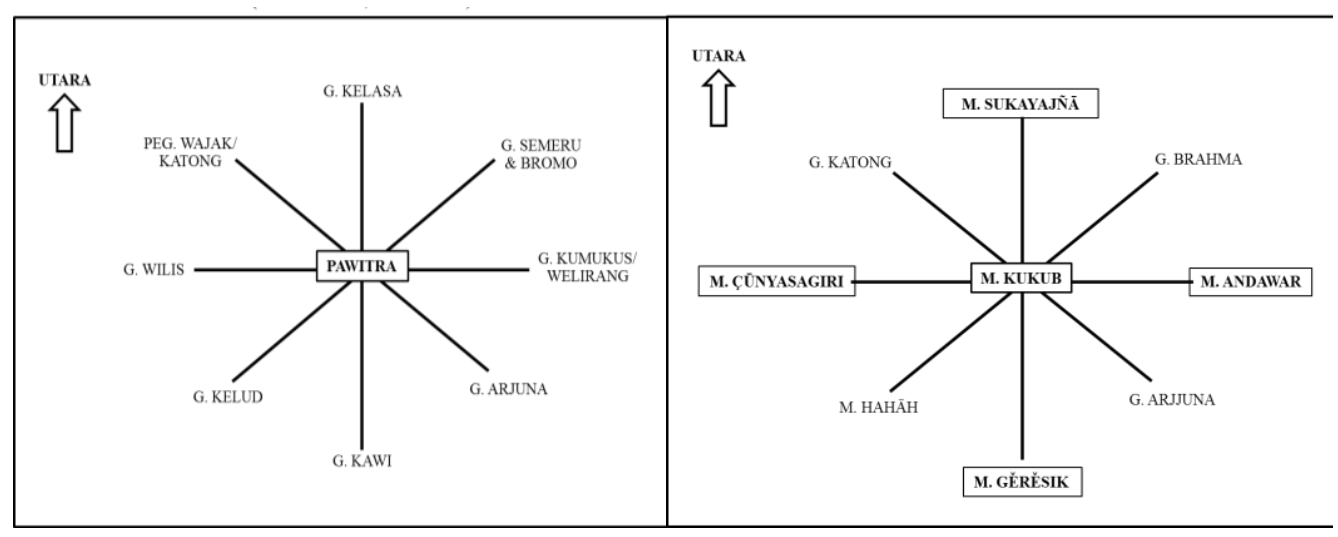

The diagram of the mandala configuration is based on the geographical location of the five mandalas located on Mount Mahameru and four cardinal directions, namely:

1. Kukub Mandala located in Mount Mahameru which also known as Mount Pawitra.

2. Sukayajñā Mandala located in Mount Kelaça, based on the mountain configuration chart with Pawitra as the center, it is placed on the north of Mount Mahameru. But in the TP text, the location of Sukayajñā mandala is stated to be located in the west of Mount Mahameru. The second disposition of the mandala changes the direction of the wind mentioned, so it also influences the disposition of the next mandala.

3. Çunnyasagiri Mandala is located to the south of Mount Mahameru, but it turns out to be in the west.

4. Gerěsik mandala is told to be located to the east of Mount Mahameru, but it turns out to be in the south. 
5. Andawar mandala is located in the north of Mount Mahameru, but it turns out to be in the east.

The existence of the five mandalas represents a change from their position in the four cardinal points. These changes can be interpreted from the direction of the west and east of Bhatāa Guru when he carries out yoga while founding the formation of a rectangular mandala.

When the island of Java imbalance, Bhatāa Guru had been carrying out yoga facing the east. The direction towards the implementation of yoga to the east is related to the place where the sun rises. In the Vedas, sunlight has a very big meaning in life. The explanation is found in Atharva Veda 17.1.30 that "the shining sun destroys all kinds of diseases. That will protect against all causes of death". Furthermore, it is also explained that "To break the bonds of death, stay connected to the sun" and "To live in the sun is the same as living in the land of immortality" (Atharva Veda 5.30.15 and 8.1.4).

That was related to the event after Bhațāra Guru carried out yoga, Dihyang appeared: yata matangnyan hana ri Dihyang ngaranya mangke, tantu bhatāra mayughā ngūni kacaritanya 'that is why there is the name Dihyang (sun) now, the sacred place of Bhatara to carry out yoga, one told' [4]. Etymologically, Dihyang (dihyay) means sun [7], so that it can be regarded that the sun as "sacred place" for bhațara to perform yoga. The sun in the east is a place of rising that provides protection from all causes of death, because it is purifying, so it is free from the bonds of death and lives in the land of immortality. Therefore, "sacred place" Dihyang is a pure place, which does not blend with other elements nor is it affected by the outside world, even has other purifying properties. In other words, the sacred place of Dihyang is the land of immortality.

However, when Bhațāra Guru will continue to make balance, he does yoga facing the west.

Kahucapa ta laksana bhatāra Guru tumulusakna magawe praçista. Mayoga ta ring ārgghanira sang hyang Mahāmeru, apatitis anggaranaçika humarěp kulon; matangnyan harěpning kahyangan kulon, apan kulwan arěpan ing bhatāra mayoga. Tumungkul mulat mingsor sira, sahulatnira mingsor matmahan Tasik-lěbu; mangkana kacaritanya.

'It is told the conduct of Bhatāra Guru will continue to make balance. He did yoga at the peak of Sang Hyang Mahameru, his eyes fixed on the tip of his nose facing west; then heaven, facing to the west, because the monastery is facing west. He lowered his head to look down, after he looked down into Tasiklebu (the sea jutting in/bay); that was the story [4].

The direction to the west during the yoga of Bhațāra Guru represents the location of the building, especially the sacred building, which is Kahyangan. In the Hindu concept, founding holy buildings, for example temples in East Java, generally faces west. In the concept of Vastu Shastra based on Hindu cosmology are:

The surface of the earth, in traditional Indian cosmology, is regarded as area demarcated by sunrise and sunset, by the point where the sun apparently emerges above and sinks below the horizon; by the East and West, and also by the North and South Points. It is therefore represented by maṇịala of square [8].

The opinion above gives the knowledge that the east and west settings are the limits of the rising and setting of the sun from the point of the sun rising above the horizon and setting below the horizon. This indicates that the cosmological arrangement is not only east and west, but also 
north and south with the counterclockwise rotation are represented at the connecting point of the rectangular mandala. As for the east-west direction the placement of rectangular mandalas in the four cardinal points follows the rotation of the sun. This shows that the chart of the mandala configuration with the Kukub mandala center represents the placement of mandalas following the clockwise rotation.

In Hindu-Buddhist religious thought, the mandala configuration can be projected as a circular rotation of pradaksina (pradaksina). Etymologically, pradakșina comes from the Sanskrit pra which means 'forwards' or 'in front of' and dakșina means 'right' or 'south' [9],[10]. The cosmic configuration can be determined by the east and west settings are the limits of the rising and setting of the sun in the prasavya circulation. In Sanskrit it comes from the pra and savya 'left', so it means moving forward around an object by placing the object on the left [9],[10]. What follows is the diagram of the cosmic configuration of Java island based on the placement of mountains and mandala formation in the TP text.

\section{Diagram of Directions West - East and East - West}

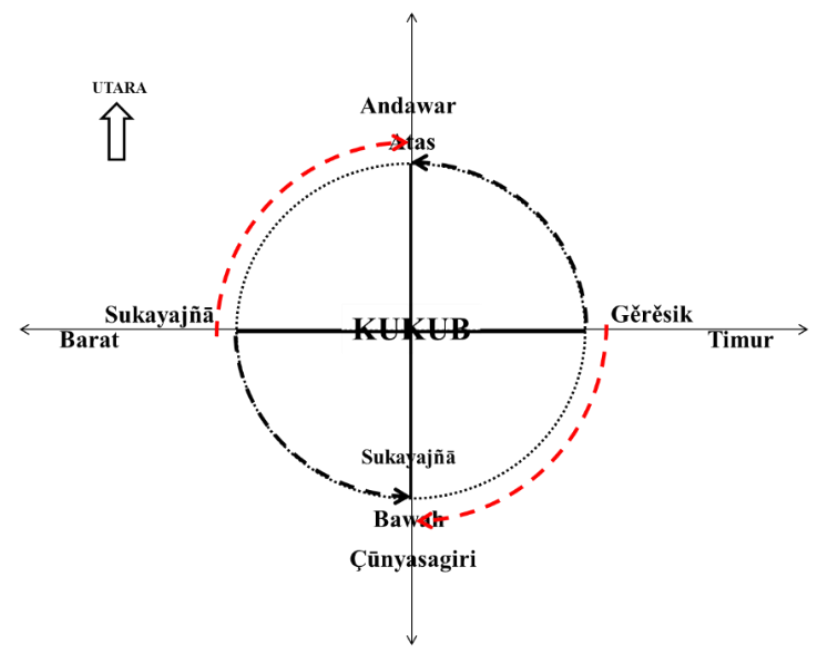

Information regarding the diagram:

- The mandala formation: west-east direction is a pradaksina rotation shown by a red dots arrow from the west to the north and east to the south.

- The placement of mountains: east-west direction represents the prasavya rotation shown by indicated by a black dots arrow that the east as the sun's rising above the horizon (running from the east to the upper horizon), and west where the sun sets below the horizon (running from west to the lower horizon) represents.

The diagram has revealed that the cosmic configuration to refers the placement of mountains and the construction of mandalas in the TP text centered on Mount Mahameru (Pawitra). The placement of mountains represents the pattern of prasavya and the construction of mandalas represents the pattern of pradaksina [4]. 
The pradaksina and prasavya perspectives in the TP text based on heritage HinduBuddhist thought have specificity in the formation of the cosmic configuration of Java Island. That cosmic configuration to refers the placement of mountands the formation of the mandala in the TP text follows the rotation of the pradaksina and prasavya, so it is clear that it is a "new world formation" within the framework to balance the island of Java.

Pradaksina pattern in Buddhism is a ritual around a holy place, a temple, a stupa, a tomb of a cleric, and/or a sacred object. The purpose of the ritual is to make amends. If there is an error in carrying out the ritual, by performing the ritual of pradaksina, then the mistake can be sanctified. In other words, the underlying conception of the formation of the mandala as the means to balance the island of Java by conducting pradaksina, it can be interpreted as a form of sanctification of Java.

The other side, prasavya pattern indicate a direction of a formed the sacred zone to be strongs "new world formation" in Java Island. So it is clear that the prasavya pattern can be interpreted as a formed of the sacred zone of Java Island centered on the Kukub mandala at the Mount Mahameru (Pawitra).

Overall, purification of the island of Java is based on the cosmic configuration with a central point in Kukub mandala located in the area of Mount Mahameru. Kukub Mandala is the Kahyangan of Bhatāara Guru [4]. Bhațāra Guru in the TP text is none other than Bhațāra Parameçwara as the Supreme God or the Highest Truth. The Supreme God is at the center or in the holy zone (absolute reality zone). Thus, the cosmic configuration in the TP text as a form of sanctification of the island of Java occupied by Bhațāra Parameçwara, and at the same time constitutes the formation of the sacred zona of the Highest Truth.

\section{CONCLUSIONS}

Based on the discussion, the idea of pradaksina and prasavya in TP text is to realize the balance of Java. The pradaksina and pracavya pattern refers to the direction of Bhatāa Guru when he performs yoga facing west and east. That direction of west and east, in Hindu-Buddhist thought, represents a complementary unity in the relationship of the macrocosm. It was applied to the activities of the placement of mountains and the formation of mandalas which represented the purification and confirmation of the sacred zone of Java. These ideas can be considered as the balancing of Java Island from the Supreme Truth (Bhațāra Guru).

That is why the placement of mountains and the formation of mandalas as a haritage of new Old Javanese prose (late Majapahit era) which is different from old prose. In old prose, it is known that the large mountains in Jambudwipa stretch in the north-south direction, while in new prose, the placement is east-west. Overall, it can be stated that pattern of pradaksina and prasavya it's embodiment as a heritage of Hindu-Buddhist thought which are intertwined in the $\mathrm{TP}$ as a haritage of new Old Javanese prose text with a complete and comprehensive story.

\section{REFERENCES}

[1] H. Santiko, "Mandala (kadewaguruan) pada jaman Majapahit.," in Pertemuan Ilmiah Arkeologi IV, 1986, p. 149-168.

[2] A. A. Munandar, Ibukota Majapahit, Masa Jaya dan Pencapaian. Depok: Komunitas Bambu, 2008.

[3] E. Sedyawati, Śaiwa dan Bauddha di Masa Jawa Kuna. Denpasar: Penerbit Widya 
Dharma, 2009.

[4] T. G. T. Pigeaud, De Tantu Panggelaran, een Oud-Javaansch prozageschrift, uitgegeven, vertaald en toegelicht's. Gravenhage, 1924.

[5] G. Tucci, The Theory and Practice of the Mandala: With special reference to the modern psychology of the subconscious. Transleted from the Italian by Alan Houghton Brodrick. London: Rider \& Company, 1969.

[6] A. A. Munandar, Arkeologi Pawitra. Jakarta: Wedatama Widya Sastra, 2016.

[7] P. J. Zoetmulder, Kamus Jawa Kuna Indonesia. Jakarta: PT Gramedia Pustaka Utama, 2006.

[8] S. Kramrisch, The Hindu Temple I. Calcutta: University of Calcutta, 1946.

[9] A. A. MacDonell, A Practical Sanskrit Dictionary. Oxford: Oxford University Press, 1974.

[10] Monier-Williams and Sir-Monier, A Sanskrit-English Dictionary. Delhi, Patna, Waranas: Motilal Banarsidass, 1986. 